Pécsi Tudományegyetem, Általános Orvostudományi Kar, Arc-, Állcsont és Szájsebészeti Tanszék* Semmelweis Egyetem, Fogorvostudományi Kar, Arc-, Állcsont-, Szájsebészeti és Fogászati Klinika, Budapest**

\title{
A vérzékeny betegek fogorvosi ellátása
}

\author{
DR. SZALMA JÓZSEF*, DR. JOÓB-FANCSALY ÁRPÁD**
}

A Magyar Arc-, Állcsont- és Szájsebészeti Társaság

és a Magyar Fogorvosok Implantológiai Társaságának ajánlásával, 2015.

\begin{abstract}
Szerzők célja a gyógyszer indukálta vérzékeny betegek fogorvosi ellátásához segítséget nyújtó, korszerű ajánlás ismertetése, a MAÁSZT (Magyar Arc-, Állcsont- és Szájsebészeti Társaság) és a MAFIT (Magyar Fogorvosok Implantológiai Társasága) jóváhagyásával.
\end{abstract}

Kulcsszavak: vérzékeny beteg, fogászati ellátás, fogorvosi ellátás, ajánlás

A fogorvosi, szájsebészeti betegellátás során szinte mindennap kezelünk fokozott vérzést okozó gyógyszert szedő pácienseket. Ezen betegcsoport ellátása kihívás lehet mind a vérzésveszély, mind a tromboembóliás komplikációk miatt. A fogorvosi diplomával járó jogosultság korlátai miatt gyakran válik szükségessé az általános orvosi diszciplínákkal történő együttműködés. A szükséges és ajánlott konzultációk és együttmúködés mellett a felesleges betegutak elkerülésére is törekednünk kell, természetesen mindig maximálisan szem előtt tartva a betegek biztonságos ellátását.

Az ajánlással kapcsolatban kiemelendő tény, hogy a tromboembóliás szövődmények a gyógyszerelések megváltoztatásával (pl. kumarinok átállítása alacsony molekulasúlyú heparinra) szignifikánsan gyakoribbak (0,8\%, melyből $0,2 \%$ letális!), mint átállítás nélkül (0\%), míg az intézeti ellátást igénylő posztoperatív vérzésveszély mindkét esetben hasonló $(0,5-0,6 \%)[20,21]$. Továbbá meg kell említenünk azt is, hogy a korrekt lokális vérzéscsillapítás költségei - a jelen társadalombiztosítási finanszírozás mellett - nagyságrendileg a térített összeg dupláját róják az ellátókra, ami mielőbbi változtatást igényelne.

Jelen írásunkkal szándékunkban állt - a megjelölt szakmai társaságok jóváhagyásával - kidolgozni egy egységes és korszerű hazai ajánlást, ami összhangban van a szakirodalomban fellelhető tudományos és kutatási eredményekkel, valamint ajánlásokkal, továbbá segíteni kívánjuk a fogorvosok és az általános orvoskollégák együttműködését ezen betegcsoportok ellátásában.

\section{Az ajánlások körébe tartozó, vérzéssel járó fogorvosi beavatkozások meghatározása}

Fogeltávolítás, feltárással járó fog-, illetve foggyökér-eltávolítás, gyökércsúcs-rezekció, parodontális szondázás, szupra- és szubgingivális fogkőeltávolítás, alveoluskorrekció, implantátum behelyezése, abscessus intraorális incíziója.

\section{Orális anti-trombotikus kezeléssel kapcsolatos ajánlások}

(TAG = trombocita aggregációgátlók, $\mathrm{VKA}=\mathrm{K}$ vitamin antagonisták,

NOAC = úgynevezett új orális antikoagulánsok; (lásd az 1. táblázat) [14, 19-24]

a) Nem ajánlott felfüggeszteni az úgynevezett „single” (aspirin v. clopidogrel v. ticlopidine) és az úgynevezett „duál” (általában aspirin és clopidogrel együtt) TAG kezeléseket sem.

b) Nem ajánlott felfüggeszteni a VKA (hydroxikumarin, acenokumarin, phenprocoumon) kezelést, ha az INR (protrombinidő, Nemzetközi Normalizált Ráta) $\leq 3,5$.

c) Nem ajánlott felfüggeszteni a NOAC („xaban”-ok, dabigatran) kezelést.

\section{Preoperatív tanácsok [2, 5, 6, 8, 13-18, 22, 23]}

a) A beavatkozás közben esetlegesen előforduló fokozott vérzésre célszerű felhívni a páciens figyelmét. 
b) VKA esetén 24-72 órával a fogorvosi kezelés előtt az INR értéket ellenőrizni kell. Amennyiben a 3,5 $\leq$ INR, a kezelőorvossal, illetve az „antikoaguláló team"-el (háziorvos, belgyógyász, kardiológus, haematológus stb.) konzultálni szükséges és kérni kell a VKA adagolás módosítását, hogy az INR elérje a kívánatos 3,5 alatti értéket, avagy LMWH-ra (Low Molecular Weight Heparin, azaz alacsony molekulasúlyú heparin) történő átállítást kell kérni („bridging”) és/vagy intézeti beutalás javasolt. Intézeti beutalás esetén az anamnézisre és korábbi kezelésekre vonatkozó dokumentációt (pl. zárójelentések stb.) javasolt összegyưjteni és mellékelni.

c) VKA-t szedő betegnél a vérzés esélye nagyobb, ha a véralvadást egyébként is befolyásoló betegség is szerepel az anamnézisben (májbetegség, vesebetegség, trombocita rendellenességek).

d) NOAC szedőknél a páciens a fogorvosi kezelés előtt lehetőleg több mint 1-3 órával vegye be a gyógyszerét. Amennyiben megoldható, inkább a gyógyszer megszokott napi bevételi időpontja előtt közvetlenül történjen a fogorvosi beavatkozás. NOAC szedése esetén az INR/PTR (protrombin) értékek félrevezetőek és nem adekvátak, ezért meghatározásuk szükségtelen.

e) Fogorvosi kezelés során három fognál többet ne távolítsunk el egyszerre! Három implantátum beültetésénél többet nem javasolt egy ülésben végezni. Időzítsük a kezeléseket a hét elejére és a rendelések kezdetére, amennyiben lehetséges.

\section{Peri/intra/operatív tanácsok [19-21]}

a) Törekedni kell a trauma minimalizálására és javasolt egy kvadránsra lokalizálni a beavatkozást.

b) Lehetőleg felszívódó suturával primeren zárjunk minden extrakciós sebet, kollagén v. oxidált cellulózszivacsok felhasználásával.

Vérzékenységet okozó gyógyszerek fogorvosi szempontból fontos farmakológiája [1-4, 7-12, 16, 17]

\begin{tabular}{|c|c|c|c|c|c|c|c|}
\hline \multirow{2}{*}{$\begin{array}{l}\text { Véralvadásgátló } \\
\text { szer jellemzői }\end{array}$} & $\begin{array}{l}\text { acetil- } \\
\text { szalicilsav }\end{array}$ & clopidogrel & $\begin{array}{l}\text { 4-hydroxi- } \\
\text { kumarin }\end{array}$ & $\begin{array}{l}\text { aceno- } \\
\text { kumarol }\end{array}$ & rivaroxaban & dabigatran & \multirow{2}{*}{$\begin{array}{l}\text { Heparin } \\
\text { / LMWH }\end{array}$} \\
\hline & \multicolumn{2}{|c|}{ trombocita aggregáció-gátlók } & \multicolumn{2}{|c|}{ K vitamin antagonisták } & \multicolumn{2}{|c|}{ ún. új orális antikoagulánsok } & \\
\hline $\begin{array}{l}\text { Gyári } \\
\text { készítményekre } \\
\text { példa } \\
\text { (a teljesség } \\
\text { igénye nélkül!) }\end{array}$ & $\begin{array}{c}\text { ASA 75-EP, } \\
\text { Aspirin rágótabletta, } \\
\text { Aspirin Protect, } \\
\text { Astrix, } \\
\text { Colfarit, } \\
\text { Kalmopyrin }\end{array}$ & $\begin{array}{c}\text { Atrombin, } \\
\text { Clopidogrel Teva, } \\
\text { Egitromb, } \\
\text { Kerberan, } \\
\text { Plagrel, } \\
\text { Plavix, } \\
\text { Trombex }\end{array}$ & \begin{tabular}{|c|} 
Marfarin, \\
Warfarin Orion
\end{tabular} & Syncumar Mite & Eliquis, Xarelto & Pradaxa & $\begin{array}{c}\text { Clexane, } \\
\text { Fragmin, } \\
\text { Fraxiparine, } \\
\text { Heparibene } \mathrm{Na}\end{array}$ \\
\hline $\begin{array}{l}\text { Hatás- } \\
\text { mechanizmus }\end{array}$ & $\begin{array}{c}\text { a thromboxan } \\
\text { A2 képződés } \\
\text { irreverzibilis } \\
\text { gátlásán keresztül } \\
\text { a thrombocyta } \\
\text { aggregáció gátlása }\end{array}$ & $\begin{array}{l}\text { ADP-receptor } \\
\text { blokkolása útján } \\
\text { akadályozza } \\
\text { a vérlemezkék } \\
\text { aggregációját }\end{array}$ & \multicolumn{2}{|c|}{$\begin{array}{c}\text { K-vitamin epoxid reduktáz gátlása, } \\
\text { gátolja a funkcionálisan aktív } \\
\text { K-vitamin dependens } \\
\text { alvadási faktorok képződését }\end{array}$} & $\begin{array}{l}\text { direkt Xa-faktor } \\
\text { inhibitor }\end{array}$ & $\begin{array}{r}\text { direkt thrombin } \\
\text { (II a) inhibitor }\end{array}$ & $\begin{array}{l}\text { anti-thrombin } \\
\text { III hatását } \\
\text { potencírozza, } \\
\text { X a, (II a) faktor } \\
\text { inaktiválás }\end{array}$ \\
\hline $\begin{array}{l}\text { A hatás } \\
\text { eléréséig } \\
\text { szükséges idő }\end{array}$ & 3-6 óra & $\begin{array}{l}\text { 1. naptól } \\
\text { jelentős gátlás, } \\
\text { 3-7. naptól } \\
\text { egyensúlyi állapot }\end{array}$ & 2-7 nap & 2-3 nap & 2-4 óra & 2-4 óra & 3-5 óra \\
\hline $\begin{array}{l}\text { Eliminációs fél } \\
\text { életidő } \\
\text { (hatástartam) }\end{array}$ & $\begin{array}{c}\text { 2-3 óra } \\
\left(8-10 \text { nap }^{*}\right)\end{array}$ & $\begin{array}{l}\text { egyszeri dózis: } \\
8 \text { óra, } \\
\text { fenntartó terápia: } \\
\text { 30-50 óra } \\
\left(5 \text { nap }^{\star}\right)\end{array}$ & $\begin{array}{l}18-70 \text { óra } \\
(2-5 \text { nap* })\end{array}$ & $\begin{array}{l}\text { 8-11 óra } \\
\left(2 \text { nap }^{*}\right)\end{array}$ & 7-11 óra & 12-17 óra & 4 óra \\
\hline $\begin{array}{l}\text { Fogorvosi } \\
\text { kezeléssel } \\
\text { kapcsolatos } \\
\text { javaslat }\end{array}$ & \multicolumn{2}{|c|}{$\begin{array}{c}\text { Nem kell leállítani, } \\
\text { lokális vérzéscsillapítás sz.e. }\end{array}$} & \multicolumn{2}{|c|}{$\begin{array}{c}3,5>\text { INR esetén } \\
\text { lokális vérzéscsillapítás }\end{array}$} & \multicolumn{2}{|c|}{$\begin{array}{l}\text { az utolsó adag utáni } \\
\text { legkésőbbi időpontban } \\
\text { kezelni a beteget }\end{array}$} & $\begin{array}{l}\text { lokális } \\
\text { vérzés- } \\
\text { csillapítás }\end{array}$ \\
\hline Antidotum & Trombocita k & részítmény & $\begin{array}{r}\text { K-vitamin ( } \\
\text { FFP (friss fagya } \\
\text { PCC (prothrombi }\end{array}$ & $\begin{array}{l}\text { Konakion); } \\
\text { Isztott plazma); } \\
\text { n komplex konc.) }\end{array}$ & $\begin{array}{c}\text { Vizsgálati } \\
\text { stádiumban: } \\
\text { Xa faktor } \\
\text { inhibitor antidótum } \\
\text { (pl. Andexanet alfa) }\end{array}$ & \begin{tabular}{|c|} 
Vizsgálati \\
stádiumban: \\
idarucizumab
\end{tabular} & $\begin{array}{l}\text { protamin- } \\
\text { szulfát }\end{array}$ \\
\hline
\end{tabular}




\section{Posztoperatív tanácsok [19-24]}

a) Beavatkozás után 15-30 percig javasolt a mútéti terület kompressziója gézlapok segítségével, valamint különösen ajánlott a tranexámsavas öblögetés [5\%-os oldattal, ami hazánkban $1 \mathrm{db} 5 \mathrm{ml}$-es Exacy ${ }^{\circledR}$ (Sanofi-Aventis, Mo.) ampulla fiziológiás sóoldattal $10 \mathrm{ml}$ mennyiségre hígítva] 1-2 napig legalább, de akár 1 hétig is; napi 4-szer, alkalmanként 2 percig a szájüregben tartva.

b) A posztoperatív vérzést legalább 1 órán keresztül kontrollálni javasolt.

c) A nem felszívódó varratokat javasolt 4-7 nap múlva eltávolítani.

d) A non-szteroid és ASA típusú fájdalomcsillapítók helyett célszerübb paracetamol és amidazophen vagy codein hatóanyagú gyógyszerek rendelése.

e) Mindenképpen szükséges a pácienseket szóban és írásban is tájékoztatni a lehetséges szövődményekröl, különös tekintettel az utóvérzések otthoni ellátási lehetőségeiről és korlátairól, valamint az intézeti/ügyeleti elérhetőségekről.

\section{Irodalom}

1. Az Egészségügyi Minisztérium szakmai irányelve: $A$ haemophilia kezeléséről. Készítette: A Transzfúziológiai és Haematologiai Szakmai Kollégium. Egészségügyi Közlöny 2011; 18: 3005-3018.

2. Bajkin BV, Urosevic IM, Stankov KM, Petrovic BB, Bajkin IA: Dental extractions and risk of bleeding in patients taking single and dual antiplatelet treatment. Br J Oral Maxillofac Surg 2014 Október 10. [Epub] doi: 10.1016/j.bjoms.2014.09.009.

3. BLASKó GY: Miképpen módosítsunk az alvadásgátló kezeléseken fogászati/szájsebészeti beavatkozások során? Orvosok Lapja 2014; 10: 28-31.

4. Boehringer Ingelheim Press Release - 30 June 2014. U.S. FDA grants Breakthrough Therapy Designation to Pradaxa ${ }^{\circledR}$ (dabigatran etexilate) specific investigational antidote. http://www. boehringer-ingelheim.com/news/news_releases/press_releases /2014/30_june_2014_dabigatranetexilate.html Last accessed November 2014.

5. Broekema FI, Van Minnen B, Jansma J, Bos RR: Risk of bleeding after dentoalveolar surgery in patients taking anticoagulants. Br J Oral Maxillofac Surg 2014; 52: e15-19. doi: 10.1016/j.bjoms. 2014.01.006.

6. Dager WE, Gosselin RC, Kitchen S, Dwyre D: Dabigatran effects on the international normalized ratio, activated partial thromboplastin time, thrombin time, and fibrinogen: a multicenter, in vitro study. Ann Pharmacother 2012; 46: 1627-1636.

7. Davis C, Robertson C, Shivakumar S, Lee M: Implications of Dabigatran, a direct thrombin inhibitor, for oral surgery practice. J Can Dent Assoc 2013; 79: d74.
8. FAVALORO EJ, LIPPI G: The new oral anticoagulants and the future of haemostasis laboratory testing. Biochem Med (Zagreb) 2012; 22: 329-341.

9. Joób-Fancsaly Á, Barabás JB, Horváth C, Kalmár G, Koppány F: Véralvadásgátló gyógyszerek alkalmazásának aktuális kérdései a fogorvosi és szájsebészeti kezelések során. Fogorv Szle 2008; 101: 147-153

10. Kachelman S, Lörincz Á, Joób-Fancsaly Á: Antikoaguláns kezelésben részesülő betegek szájsebészeti ellátásának klinikai vizsgálata. Fogorv Szle 2012; 105: 53-58.

11. Magyar Thrombosis és Haemostasis Társaság; Transzfuziológiai és Haematológiai Szakmai Kollégium. A thromboembolia kockázatának csökkentése és kezelése. Orv Hetil 2009; 150: 23352404. doi: $10.1556 / \mathrm{OH} .2009 .28789$.

12. NEFMI szakmai irányelv a hematológiai betegségek korszerú kezeléséről - a véralvadási zavarok korszerü kezelése. Készítette: A Transzfúziológiai és Haematologiai Szakmai Kollégium. https:// kollegium.gyemszi.hu/conf/upload/oldiranyelvek/TRANSZF_veralvadasi\%20zavarok\%20korszeru\%20kezelese_mod0_v0.pdf

13. O'RIORDAN M: Falsely elevated point-of-care INR values in dabigatran-treated patients. Heartwire 2011. Júl. 7. http://www.t heheart.org/article/1251461.do.

14. Patel N, Patel V, Sarkar D, Nokes T, Blacklock P: Dual antiplatelet therapy and dento-alveolar surgery. How do we manage patients on anti-platelet medication? Br Dent J 2014; 217: E24. doi: 10.1038/sj.bdj.2014.1055.

15. Peisker A, Raschke GF, Schultze-Mosgau S: Management of dental extraction in patients with Haemophilia $A$ and $B$ : a report of 58 extractions. Med Oral Patol Oral Cir Bucal 2014; 19(1): e55-60.

16. Perry DJ, Noakes TJ, Helliwell PS; British Dental Society: Guidelines for the management of patients on oral anticoagulants requiring dental surgery. Br Dent J 2007; 203: 389-393.

17. Samama MM, Martinoli JL, Leflem L: Assessment of laboratory assays to measure rivaroxaban - an oral, direct factor Xa inhibitor. Thromb Haemost 2010; 103: 815-825.

18. Siller-Matula JM, Krumphuber J, Jilma B: Pharmacokinetic, pharmacodynamic and clinical profile of novel antiplatelet drugs targeting vascular diseases. Br J Pharmacol 2010; 159: 502517.

19. Svensson R, Hallmer F, Englesson CS, Svensson PJ, Becktor JP: Treatment with local hemostatic agents and primary closure after tooth extraction in warfarin treated patients. Swed Dent J 2013; 37: 71-77.

20. van Diermen DE, van der Waal I, Hoogstraten J: Management recommendations for invasive dental treatment in patients using oral antithrombotic medication, including novel oral anticoagulants. Oral Surg Oral Med Oral Pathol Oral Radiol 2013; 116: 709-716.

21. Wahl MJ, Pinto A, Kilham J, Lalla RV: Dental surgery in anticoagulated patients - stop the interruption. Oral Surgery, Oral Medicine, Oral Pathology and Oral Radiology 2014. November 12. [Epub]. doi: 10.1016/j.0000.2014.10.011.

22. www.dgzmk.de/uploads/tx_szdgzmkdocuments/Zahnaerztliche_ Chirurgie_bei_Patienten_mit_Antikoagulanzientherapie.pdf

23. www.knmt.nl/_C1256DE2004732BC.nsf/vlBijlage/Richtlijn_ ACTA_antistolling_juni2012.pdf/\$File/Richtlijn_ACTA_ antistolling_juni2012.pdf 
SZALMA J, JoÓB-FANCSALy Á

The Hungarian guideline for the management of patients on oral anticoagulants and anti-platelet therapy requiring dental treatment and surgery

Authors presented a proposal of dental treatment and management of anticoagulated patients and of patients on antiplatelet therapy, in agreement with the Hungarian Association of Oral and Maxillofacial Surgeons and in agreement with the Dental Implantology Association of Hungarian Dentists. This current guide was based on recent Hungarian and on several foreign national guidelines and considers significant publications from international literature.

Keywords: national guideline, anti-platelet therapy, anticoagulation, dental treatment, dental surgery

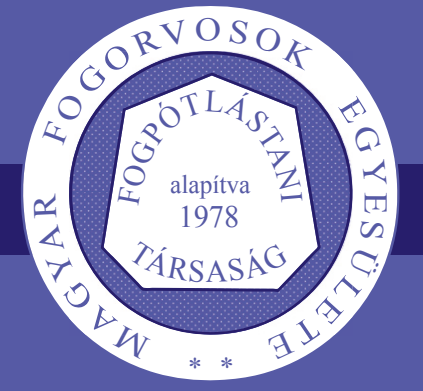

\section{FOGPÓTLÁSTANI NAPOK Pécs, 2015. szeptember 24-26.}

Magyar Fogorvosok Egyesületének Fogpótlástani Társasága XXI. kongresszus és továbbképzö tanfolyam

Az érem két oldala: Aktuális témakörök a fogpótlástanban a fogorvos és a fogtechnikus szemszögéböl Továbbképző tanfolyam fogorvosok és fogtechnikusok számára 2015. szeptember 24.

Implantációs és digitális fogpótlástan a 21. században A Magyar Fogorvosok Egyesületének Fogpótlástani Társaságának XXI. kongresszusa 2015. szeptember 25.

A fogpótlástan korszerủ anyagai és technikái Továbbképző tanfolyam fogorvosok számára 2015. szeptember 26.

Prof. Dr. Hegedüs Csaba, elnök MFE Fogpótlástani Társasága 